\title{
Satellite and Ground-Based Observations of Explosive Eruptions on Zhupanovsky Volcano, Kamchatka, Russia in 2013 and in 2014-2016
}

\author{
O. A. Girina* ${ }^{* a}$, E. A. Loupian ${ }^{b}$, A. A. Sorokin ${ }^{c}$, D. V. Mel'nikov ${ }^{a}$, \\ A. G. Manevich ${ }^{a}$, and T. M. Manevich ${ }^{a}$ \\ ${ }^{a}$ Institute of Volcanology and Seismology, Far East Branch, Russian Academy of Sciences, \\ b-r Piipa, 9, Petropavlovsk-Kamchatskii, 683006 Russia \\ ${ }^{b}$ Institute of Space Research, Russian Academy of Sciences, \\ ul. Profsoyuznaya, 38/32, Moscow, 117997 Russia \\ ${ }^{c}$ Computation Center, Far East Branch, Russian Academy of Sciences, \\ ul. Kim Yu Chena, 65, Khabarovsk, 680000 Russia \\ *e-mail: girina@kscnet.ru \\ Received May 31, 2017
}

\begin{abstract}
The active andesitic Zhupanovsky Volcano consists of four coalesced stratovolcano cones. The historical explosive eruptions of 1940, 1957, and 2014-2016 discharged material from the Priemysh Cone. The recent Zhupanovsky eruptions were studied using satellite data supplied by the Monitoring of Active Volcanoes in Kamchatka and on the Kuril Islands information system (VolSatView), as well as based on video and visual observations of the volcano. The first eruption started on October 22 and lasted until October 24, 2013. Fumaroles situated on the Priemysh western slope were the centers that discharged gas plumes charged with some amount of ash. The next eruption started on June 6, 2014 and lasted until November 20, 2016. The explosive activity of Zhupanovsky was not uniform in 2014-2016, with the ash plumes being detected on satellite images for an approximate total duration of 112 days spread over 17 months. The most vigorous activity was observed between June and October, and in November 2014, with a bright thermal anomaly being nearly constantly seen on satellite images around Priemysh between January and April 2015 and in January-February 2016. The 2014-2016 eruption culminated in explosive events and collapse of parts of the Priemysh Cone on July 12 and 14, November 30, 2015, and on February 12 and November 20, 2016.
\end{abstract}

DOI: $10.1134 / \mathrm{S} 0742046318010049$

\section{INTRODUCTION}

The active andesitic Zhupanovsky Volcano $\left(53^{\circ} 35^{\prime} \mathrm{N}\right.$, $159^{\circ} 9^{\prime} \mathrm{E}, 2958 \mathrm{~m}$ ) is situated in southeastern Kamchatka, $40 \mathrm{~km}$ from the Avachinsky-Koryaksky Volcanic Group (Fig. 1). Its edifice is a ridge consisting of four coalesced stratovolcano cones (Masurenkov et al., 1991). Some authors regard only the first two cones (from the east) as Zhupanovsky Volcano and treat the Priemysh and Bastion cones as distinct volcanoes (Litvinov and Burmakov, 1993; Bazanova et al., 2009). The active Priemysh Cone (2773 m) is adjacent to the second Zhupanovsky cone, counting from the west; it has a crater $450 \mathrm{~m}$ in diameter and a funnel $80 \mathrm{~m}$ across in the crater, near its southwestern wall (Litvinov and Burmakov, 1993). The basement of Priemysh is composed of thick dacite lavas and tuffs due to Late Pleistocene pyroclastic flows, which overlie the ruins of the Middle Pleistocene Treugol'nik Massif and of the Pliocene Klyk Volcano (Puzankov et al., 2015). The creation of the Priemysh Cone began $\sim 3500-3000{ }^{14} \mathrm{C}$ years ago (Bazanova et al., 2009). Its ejecta range from orthopyroxene dacites to pyroxene andesites; the eruptions have been mostly effusive; the time span of $3500-1800^{14}$ C B.P. saw practically continuous explosive eruptions (Bazanova et al., 2009). Only two large explosive eruptions ( 2100 and $700-$ $800{ }^{14} \mathrm{C}$ B.P.) accompanied by heavy ashfalls have been determined; the earlier of these produced pyroclastic pumice flows.

In historical times, small and moderate eruptions emanating from Priemysh itself occurred in 1940, 1957, 2013, and 2014-2016 (Girina and Nenasheva, 2015; Girina et al., 2014, 2016, 2016a, 2016b; Puzankov et al., 2015; Sirin, 1958). The time values in this paper are all UTC.

\section{MONITORING THE ACTIVITY OF ZHUPANOVSKII VOLCANO}

The Kamchatkan Volcanic Eruption Response Team (KVERT) operated by the Institute of Volcanology and Seismology, Far East Branch, Russian Acad- 


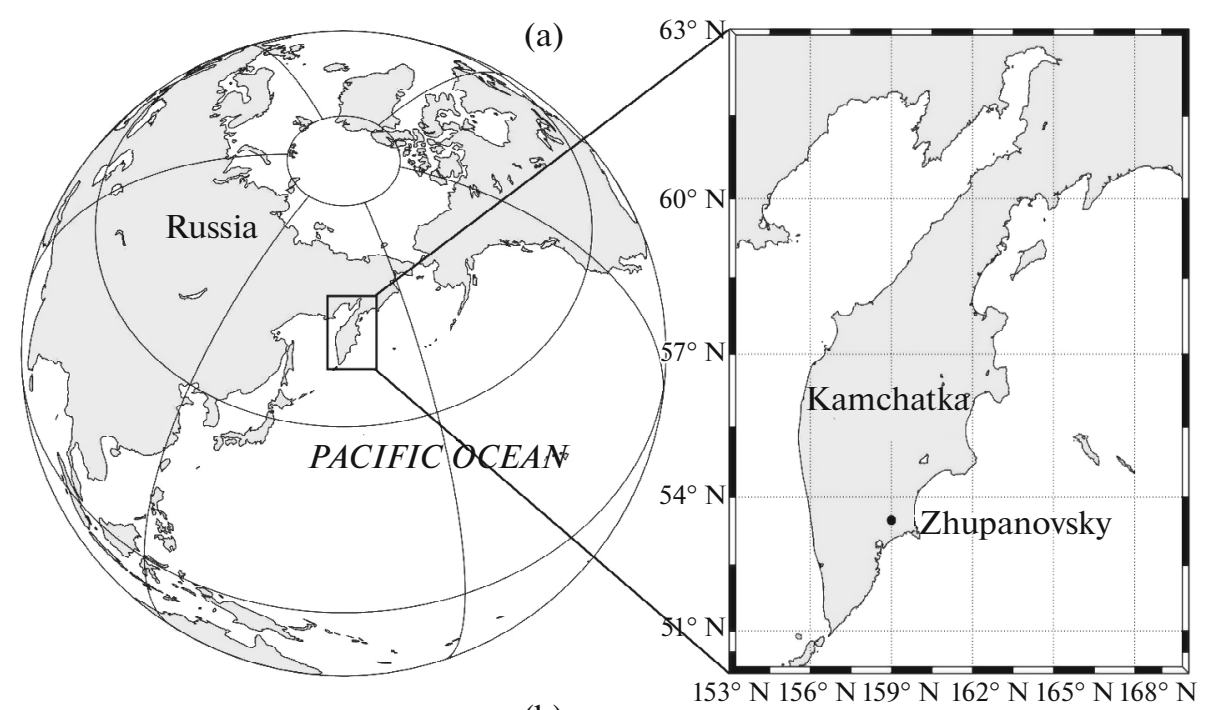

(b)

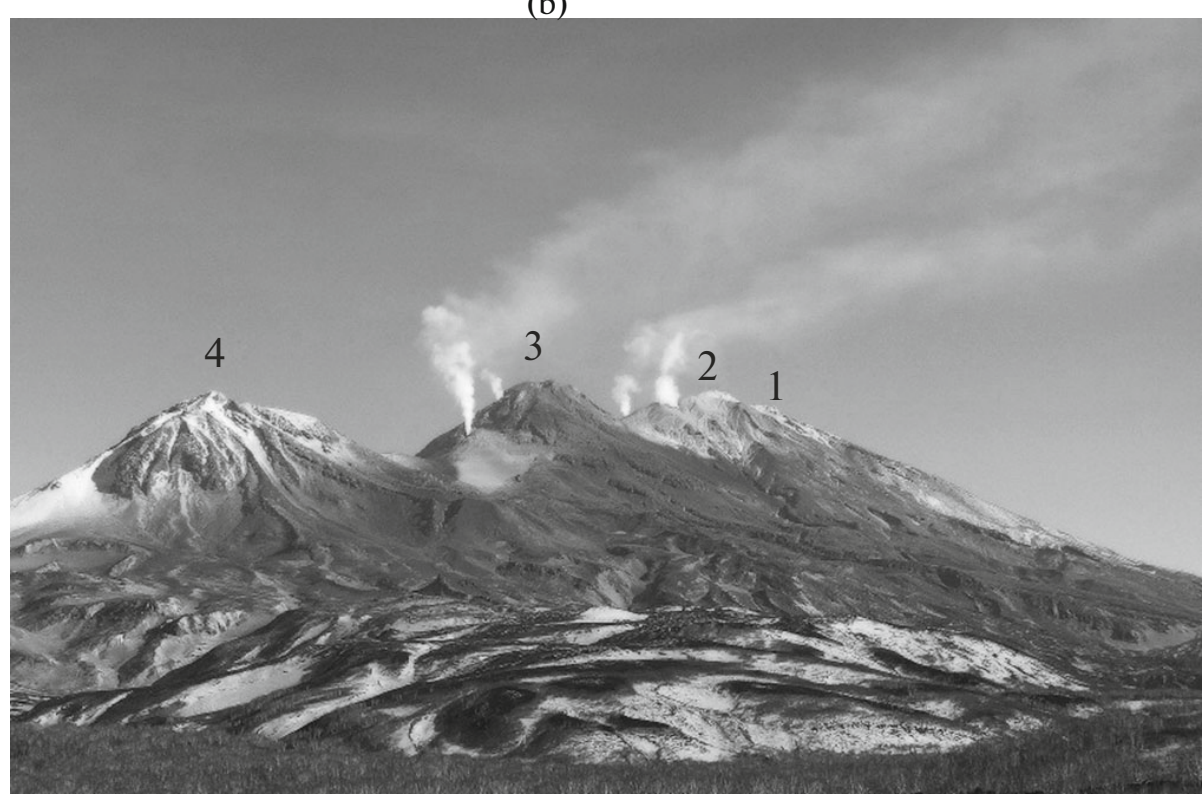

Fig. 1. The location (a) and a general form of Zhupanovsky Volcano on October 26, 2013 (1, 2, eastern summits of the volcano; 3, Priemysh; 4, Bastion, photographed by S. Samoilenko (b).

emy of Sciences (IVS FEB RAS) has been conducting daily satellite-based monitoring of Zhupanovsky Volcano since 2002 (Gordeev and Girina, 2014; http://www.kscnet.ru/ivs/kvert/). Satellite-based monitoring is the leading method of observation of the volcano, because it is out of direct visibility of the population centers (Zhupanovsky is $70 \mathrm{~km}$ north of the town of Petropavlovsk-Kamchatskii beyond the Avachinsky-Koryaksky Volcanic Group). The nearest seismic stations operated by the Kamchatka Branch of the Federal Research Center, Geophysical Survey (KB FRC UGS) are in the environs of Avachinsky and Koryaksky volcanoes, that is, $38 \mathrm{~km}$ from Zhupanovsky (Senyukov et al., 2015). Only some fragmentary data for 2013-2014 and for JanuaryApril, September-November 2015 are available to
KVERT; these consist in visual observations of the volcano furnished by volcanologists, colleagues at the Volcanoes of Kamchatka Nature Park, and tourists. A video camera was installed by the KB FRC UGS RAS in the area of Lake Nalychevo $(52 \mathrm{~km}$ from the volcano) on May 13, 2015 (Senyukov et al., 2015); it took videos at intervals of 2 to 5 minutes in May-August 2015 and 30 minutes in December 2015 and in 2016.

Since 2013, the satellite-based monitoring of the volcano was conducted using the Monitoring of Volcanic Activity in Kamchatka and on the Kuril Islands information system (IS) (VolSatView, http://volcanoes.smislab.ru), which allows integrated handling of different satellite data (NOAA (an AVHRR instrument), Terra and Aqua (MODIS), Suomi NPP 
(VIIRS), Meteor-M (1, 2); Himawari-8, Landsat (4, 5, 7, and 8), EO-1 Hyperion, Kanopus-V, Resurs $\mathrm{P}$, and others), as well as of weather and ground-based data, the results from simulation of ash plume propagation for continuous monitoring, and results from studies of volcanic activity in the Kuril-Kamchatka region (Gordeev et al., 2016).

\section{THE 2016 EXPLOSIVE ERUPTION OF THE VOLCANO}

According to satellite data, the first explosive eruption of Zhupanovsky Volcano began on October 22, 2013 (Girina and Nenasheva, 2015). The first ash plume $48 \mathrm{~km}$ long (azimuth $122 \mathrm{deg}$.) was detected at 00:51 UTC on October 22 in a NOAA-16 image (Girina et al., 2014). Ash plumes were observed nearly all the time during October 22-24; they carried low or moderate amounts of ash at heights of $3.0-4.0 \mathrm{~km}$ above sea level (a.s.l.) and were mostly traveling southeast, south, and southwest from the volcano (Table 1, Fig. 2). We note that several workers (Samoilenko et al., 2014; Senyukov et al., 2015; among others) described the eruption as having started at 15:00 UTC on October 23 (as reported by observers from out the Volcanoes of Kamchatka Nature Park); however, satellite data gave a more accurate time.

The NOAA-18 image taken at 04:35 UTC on October 24 recorded the longest ash plume $(120 \mathrm{~km})$, while no ash plumes due to Zhupanovsky were detected after 23:34 UTC on that day (VONA KVERT 2013-26).

Visual observations showed that the most vigorous activity on October 24 and 26 was due to fumaroles on the western slope of Priemysh and on the bridge between it and the second cone of Zhupanovsky (see Fig. 1) (Girina and Nenasheva, 2015). According to an ASTER image (00:44 UTC October 26, 2013, the Geo Grid Data, Japan), ash mostly lay on the southern slope of the volcano. Snow was observed to lie in the crater of the Priemysh Cone on October 26, 2013, with the ash being $15-20 \mathrm{~cm}$ thick near the fumaroles on the western slope of Priemysh (Samoilenko et al., 2014).

Retrospective analysis of seismic data from the Zhupanovsky area, as recorded by stations $38-40 \mathrm{~km}$ from the volcano, showed a slight increase in the volcano's seismic activity in August 2013 (8 events of the 18 that have been recorded in 2013) (Senyukov et al., 2015).

Summing up the above information, we note that the first recent eruption of Zhupanovsky lasted from October 22 to 24, 2013. The centers that discharged voluminous ash-charged gas plumes were fumaroles situated on the western slope of Priemysh.

\section{THE 2014-2016 EXPLOSIVE ERUPTION OF THE VOLCANO}

A new explosive eruption started at approximately 15:00 UTC on June 6, 2014 (ash rose to heights of $6 \mathrm{~km}$ a.s.l., sounds of explosions were heard coming from the volcano, and the summit of the Priemysh Cone was luminescent) (Girina et al., 2016; VONA KVERT 2014-07).

It is important to note that ash was bursting from the Priemysh vent during the entire eruption of 20142016. Discrete powerful fumarolic jets were constantly observed during the ash discharges and during the intereruptive phase along the narrow fissure on the volcano's western slope and in the rent to the east of it (described by A.N. Sirin (1958)); for example, six fumaroles were seen in the fissure on the western slope of Priemysh on June 12, 2014 (Girina et al., 2016a).

Regular (at intervals of 30-90 min) ash discharges were observed to emanate from the Priemysh vent on June 9-10 upon the background of an intensive steam-and-gas activity of the volcano (Samoilenko et al., 2014). In June-August, ash mostly rose to heights of $4-5 \mathrm{~km}$ a.s.1., ash and steam-gas plumes with small amounts of ash traveled 70-300 km, mostly eastward of the volcano; on June 12 a thermal anomaly was observed in the Priemysh area; its temperature slightly increased in August (see Table 1, Figs. 2, 3, and $4 a$ ). We note that meanwhile ash was being ejected from the funnel in the western part of the Priemysh crater. Ash rose to 7.2 and $6 \mathrm{~km}$ a.s.l. on June 19 and July 9; ash plumes traveled northeastward as far as $670 \mathrm{~km}$ and $120 \mathrm{~km}$ eastward from the volcano, respectively (see Table 1, Fig. 2).

The explosive activity was not uniform over time: visual observations showed occasional ash ejections resulting in individual ash clouds that moved locally away from the volcano; at times series of ash ejections were observed, so that a continuous ash plume was being formed. The longer a series of ash discharges lasted, the more ash was in the plume, and the farther it traveled from the volcano; satellite images then showed a continuous ash plume that extended from the Priemysh Cone itself. On one occasion, a discrete ash discharge from the Priemysh vent occurred; the corresponding satellite images showed a local ash cloud without any connection to the volcano that became longer over time and traveled downwind away from it.

The eruption grew more vigorous in September: series of ash ejections were occurring daily, along with the thermal anomaly in the volcano area (see Figs. 2, 3). According to satellite observations, the explosions of September 7 hurled ash to heights of $10-10.5 \mathrm{~km}$ a.s.l.; the ash plume extended for $1100 \mathrm{~km}$ southeast of the volcano. On other days in September, ash plumes traveled at heights of $3-4.5 \mathrm{~km}$ a.s.l. for as much as $100-200 \mathrm{~km}$ in different directions from the volcano (see Table 1, Figs. 2 and 5a). 
Table 1. Ash plumes discharged by Zhupanovsky during the eruptions of 2013 and 2014-2016 based on VolSatView IS data

\begin{tabular}{|c|c|c|c|c|c|}
\hline Date & Time, UTC & Satellite & $\begin{array}{l}\text { Length of ash } \\
\text { plume, } \mathrm{km}\end{array}$ & $\begin{array}{l}\text { Azimuth of plume } \\
\text { movement, deg }\end{array}$ & $\begin{array}{c}\text { Height of ash } \\
\text { plume, km a.s.l. }\end{array}$ \\
\hline 1 & 2 & 3 & 4 & 5 & 6 \\
\hline \multicolumn{6}{|c|}{2013 eruption } \\
\hline 22 Oct 13 & $0: 51$ & NOAA 16 & 48 & 122 & 2 \\
\hline 22 Oct 13 & $1: 05$ & TERRA & 40 & 119 & 3.5 \\
\hline 23 Oct 13 & $11: 25$ & TERRA & 21 & 124 & \\
\hline 24 Oct 13 & $0: 25$ & NOAA 16 & 87 & 185 & \\
\hline 24 Oct 13 & $4: 35$ & NOAA 18 & 120 & 185 & 3 \\
\hline 24 Oct 13 & $10: 17$ & NOAA 16 & 15 & 240 & 3.5 \\
\hline 24 Oct 13 & $10: 30$ & TERRA & 23 & 244 & \\
\hline 24 Oct 13 & $16: 19$ & NOAA 19 & 60 & 207 & \\
\hline 24 Oct 13 & $16: 52$ & NOAA 18 & 75 & 209 & 3 \\
\hline \multicolumn{6}{|c|}{ 2014-2016 eruption } \\
\hline 9 Jun 14 & $0: 31$ & TERRA & 60 & 90 & 4 \\
\hline 9 Jun 14 & $2: 47$ & NOAA 19 & 10 & 90 & \\
\hline 9 Jun 14 & $3: 49$ & NOAA 18 & 15 & 100 & \\
\hline 11 Jun 14 & 19:08 & NOAA 18 & 60 & 110 & 2.5 \\
\hline 12 Jun 14 & $2: 50$ & AQUA & 91 & 110 & \\
\hline 13 Jun 14 & $1: 55$ & AQUA & 62 & 100 & 3 \\
\hline 14 Jun 14 & $0: 50$ & TERRA & 25 & 130 & \\
\hline 16 Jun 14 & $15: 11$ & AQUA & 20 & 230 & \\
\hline 17 Jun 14 & $1: 17$ & NOAA 19 & 140 & 76 & \\
\hline 18 Jun 14 & 1:07 & NOAA 19 & 19 & 280 & 3.2 \\
\hline 18 Jun 14 & $16: 45$ & NOAA 19 & 7 & 285 & 4.5 \\
\hline 19 Jun 14 & $14: 53$ & NOAA 19 & 110 & 23 & 7.2 \\
\hline 20 Jun 14 & $0: 47$ & NOAA 19 & 670 & 47 & \\
\hline 9 Jul 14 & $23: 50$ & AQUA & 120 & 90 & 6 \\
\hline $10 \mathrm{Jul} 14$ & $1: 26$ & AQUA & 130 & 90 & \\
\hline 18 Jul 14 & $2: 18$ & NOAA 19 & 70 & 45 & 5 \\
\hline 21 Jul 14 & $1: 05$ & TERRA & 30 & 45 & 3.5 \\
\hline 27 Jul 14 & $2: 22$ & NOAA 19 & 38 & 10 & \\
\hline 6 Aug 14 & 1:06 & TERRA & 150 & 75 & 1.5 \\
\hline 11 Aug 14 & $19: 19$ & NOAA 19 & 90 & 135 & 3.5 \\
\hline 12 Aug 14 & $3: 29$ & NOAA 18 & 80 & 50 & 2 \\
\hline 13 Aug 14 & $0: 54$ & NOAA 19 & 80 & 45 & 4.5 \\
\hline 19 Aug 14 & $17: 07$ & NOAA 19 & 51 & 175 & \\
\hline 20 Aug 14 & $5: 25$ & NOAA 18 & 110 & 175 & 3 \\
\hline 28 Aug 14 & $3: 55$ & NOAA 18 & 80 & 225 & 4 \\
\hline 30 Aug 14 & $2: 06$ & AQUA & 23 & 120 & 4 \\
\hline 1 Sep 14 & $1: 54$ & AQUA & 22 & 235 & 3.5 \\
\hline 2 Sep 14 & $0: 47$ & TERRA & 12 & 230 & 4 \\
\hline 3 Sep 14 & $2: 05$ & NOAA 19 & 76 & 182 & 4 \\
\hline 4 Sep 14 & $2: 25$ & AQUA & 43 & 135 & 2 \\
\hline 7 Sep 14 & $1: 23$ & NOAA 19 & 92 & 135 & 10.5 \\
\hline 7 Sep 14 & 3:00 & NOAA 19 & 210 & 135 & 6 \\
\hline
\end{tabular}


Table 1. (Contd.)

\begin{tabular}{|c|c|c|c|c|c|}
\hline Date & Time, UTC & Satellite & $\begin{array}{l}\text { Length of ash } \\
\text { plume, km }\end{array}$ & $\begin{array}{c}\text { Azimuth of plume } \\
\text { movement, deg }\end{array}$ & $\begin{array}{c}\text { Height of ash } \\
\text { plume, km a.s.l. }\end{array}$ \\
\hline 1 & 2 & 3 & 4 & 5 & 6 \\
\hline $7 \mathrm{Sep} 14$ & $5: 16$ & NOAA 18 & 383 & 135 & 3.5 \\
\hline 8 Sep 14 & $0: 11$ & TERRA & 83 & 135 & 3 \\
\hline 9 Sep 14 & $10: 29$ & TERRA & 149 & 152 & \\
\hline 10 Sep 14 & $1: 45$ & AQUA & 112 & 175 & 3.5 \\
\hline 11 Sep 14 & $0: 45$ & TERRA & 115 & 171 & \\
\hline 13 Sep 14 & $0: 30$ & TERRA & 40 & 96 & 3 \\
\hline 14 Sep 14 & $1: 45$ & NOAA 19 & 190 & 92 & 3.5 \\
\hline 16 Sep 14 & $1: 24$ & NOAA 19 & 43 & 191 & 3.5 \\
\hline 21 Sep 14 & $22: 32$ & MTSAT & 40 & 210 & 4.5 \\
\hline 24 Sep 14 & $0: 11$ & TERRA & 79 & 212 & 4 \\
\hline 28 Sep 14 & $1: 36$ & AQUA & 52 & 91 & 4.5 \\
\hline 11 Oct 14 & $17: 13$ & Suomi NPP & 27 & 80 & 9 \\
\hline 12 Oct 14 & 0:01 & TERRA & & 57 & 5.5 \\
\hline 7 Nov 14 & $23: 44$ & NOAA 19 & 40 & 306 & 11 \\
\hline 8 Nov 14 & $1: 41$ & NOAA 19 & 22 & 263 & 7 \\
\hline 9 Nov 14 & $1: 26$ & NOAA 19 & 190 & 125 & 4 \\
\hline 10 Nov 14 & 10:40 & TERRA & 55 & 124 & \\
\hline 22 Nov 14 & $14: 40$ & NOAA 19 & 35 & 86 & 8.5 \\
\hline 22 Nov 14 & $15: 10$ & AQUA & 70 & 85 & 6.7 \\
\hline 22 Nov 14 & $15: 44$ & Suomi NPP & 115 & 84 & 5.5 \\
\hline 22 Nov 14 & $16: 23$ & NOAA 19 & 160 & 84 & 2.5 \\
\hline 22 Nov 14 & $18: 16$ & NOAA 18 & 311 & 88 & \\
\hline 22 Nov 14 & $19: 57$ & NOAA 18 & 350 & 88 & \\
\hline 25 Nov 14 & $0: 25$ & TERRA & 8 & 147 & 7.2 \\
\hline 25 Nov 14 & $0: 59$ & Suomi NPP & 30 & 222 & 6 \\
\hline 25 Nov 14 & $1: 55$ & NOAA 19 & 60 & 153 & 6 \\
\hline 25 Nov 14 & $2: 12$ & AQUA & 72 & 154 & 5.5 \\
\hline 25 Nov 14 & $2: 34$ & Suomi NPP & 86 & 144 & 5 \\
\hline 25 Nov 14 & $3: 31$ & NOAA 19 & 118 & 140 & 2.5 \\
\hline 25 Nov 14 & $5: 25$ & NOAA 18 & 197 & 133 & 2 \\
\hline 25 Nov 14 & $11: 33$ & TERRA & 203 & 140 & \\
\hline 25 Nov 14 & $14: 48$ & Suomi NPP & 230 & 160 & \\
\hline 25 Nov 14 & $15: 50$ & NOAA 19 & 270 & 155 & \\
\hline 26 Nov 14 & $1: 05$ & AQUA & 10 & 212 & \\
\hline 26 Nov 14 & 19:11 & NOAA 18 & 240 & 125 & 4 \\
\hline 27 Nov 14 & $0: 11$ & TERRA & 80 & 141 & 4 \\
\hline 28 Nov 14 & $0: 53$ & TERRA & 242 & 90 & 6 \\
\hline 29 Nov 14 & $1: 47$ & AQUA & 189 & 72 & 4 \\
\hline 30 Nov 14 & $0: 41$ & TERRA & 150 & 102 & 4 \\
\hline 30 Nov 14 & $2: 37$ & NOAA 19 & 191 & 100 & 4 \\
\hline 1 Dec 14 & $1: 35$ & AQUA & 53 & 134 & \\
\hline 15 Dec 14 & $15: 12$ & Suomi NPP & 136 & 134 & 4 \\
\hline
\end{tabular}


Table 1. (Contd.)

\begin{tabular}{|c|c|c|c|c|c|}
\hline Date & Time, UTC & Satellite & $\begin{array}{l}\text { Length of ash } \\
\text { plume, } \mathrm{km}\end{array}$ & $\begin{array}{l}\text { Azimuth of plume } \\
\text { movement, deg }\end{array}$ & $\begin{array}{c}\text { Height of ash } \\
\text { plume, km a.s.l. }\end{array}$ \\
\hline 1 & 2 & 3 & 4 & 5 & 6 \\
\hline 29 Dec 14 & $0: 11$ & TERRA & 18 & 68 & 6 \\
\hline 6 Jan 15 & $16: 25$ & NOAA 19 & 50 & 100 & \\
\hline 12 Jan 15 & $2: 12$ & AQUA & 26 & 251 & 5 \\
\hline 16 Jan 15 & $1: 47$ & TERRA & 20 & 260 & \\
\hline 17 Jan 15 & $14: 54$ & Suomi NPP & 184 & 103 & 5 \\
\hline 18 Jan 15 & $0: 46$ & Suomi NPP & 50 & 154 & 4 \\
\hline 19 Jan 15 & $0: 29$ & TERRA & 45 & 125 & 3.5 \\
\hline 20 Jan 15 & $1: 25$ & TERRA & 17 & 71 & 4 \\
\hline 22 Jan 15 & $18: 26$ & NOAA 18 & 5 & 281 & 4 \\
\hline 25 Jan 15 & $2: 19$ & NOAA 19 & 28 & 244 & 5 \\
\hline 26 Jan 15 & $0: 35$ & TERRA & 8 & 243 & 3 \\
\hline 6 Feb 15 & $2: 04$ & AQUA & 29 & 265 & 3 \\
\hline 9 Feb 15 & $2: 35$ & AQUA & 23 & 290 & 3 \\
\hline 15 Feb 15 & $17: 22$ & NOAA 19 & 65 & 266 & 3.5 \\
\hline 16 Feb 15 & $0: 53$ & AQUA & 70 & 267 & \\
\hline 17 Feb 15 & $18: 30$ & NOAA 18 & 44 & 137 & \\
\hline 18 Feb 15 & $5: 59$ & NOAA 18 & 44 & 158 & 3 \\
\hline 19 Feb 15 & $0: 45$ & Suomi NPP & 134 & 116 & 3 \\
\hline 20 Feb 15 & $5: 38$ & NOAA 18 & 38 & 100 & 2.5 \\
\hline 21 Feb 15 & $5: 27$ & NOAA 18 & 80 & 105 & 3 \\
\hline 22 Feb 15 & $15: 17$ & Suomi NPP & 204 & 102 & 2.5 \\
\hline 23 Feb 15 & $1: 00$ & AQUA & 223 & 108 & 3.5 \\
\hline 1 Mar 15 & $5: 33$ & NOAA 18 & 10 & 70 & 3 \\
\hline 4 Mar 15 & $10: 30$ & TERRA & 48 & 94 & 8 \\
\hline 7 Mar 15 & 20:04 & NOAA 18 & 333 & 92 & 8 \\
\hline $8 \operatorname{Mar} 15$ & $2: 19$ & AQUA & 88 & 67 & 8 \\
\hline 8 Mar 15 & $2: 52$ & NOAA 19 & 141 & 65 & 5 \\
\hline 8 Mar 15 & $4: 20$ & NOAA 18 & 307 & 71 & 3 \\
\hline 10 Mar 15 & $2: 31$ & NOAA 19 & 187 & 96 & 3.5 \\
\hline 12 Mar 15 & $6: 37$ & NOAA 18 & 7 & 55 & \\
\hline 15 Mar 15 & $10: 10$ & TERRA & 76 & 197 & 3.5 \\
\hline 15 Mar 15 & $11: 46$ & TERRA & 168 & 71 & 0.5 \\
\hline 15 Mar 15 & $15: 23$ & Suomi NPP & 346 & 182 & \\
\hline 25 Mar 15 & $4: 26$ & NOAA 18 & 10 & 85 & 8 \\
\hline 3 Apr 15 & $3: 02$ & NOAA 19 & 25 & 112 & 4 \\
\hline 20 May 15 & $10: 00$ & TERRA & 53 & 82 & 6 \\
\hline 8 Jun 15 & $6: 45$ & NOAA 19 & 26 & 135 & \\
\hline 9 Jun 15 & $0: 00$ & AQUA & 95 & 177 & 6 \\
\hline 16 Jun 15 & $15: 25$ & AQUA & 8 & 275 & 4.7 \\
\hline 12 Jul 15 & $6: 57$ & NOAA 18 & 75 & 97 & 10.5 \\
\hline 12 Jul 15 & $10: 20$ & TERRA & 328 & 124 & 6.5 \\
\hline 12 Jul 15 & $11: 53$ & TERRA & 488 & 116 & 5.5 \\
\hline 12 Jul 15 & $14: 25$ & AQUA & 653 & 111 & 4 \\
\hline
\end{tabular}


Table 1. (Contd.)

\begin{tabular}{|c|c|c|c|c|c|}
\hline Date & Time, UTC & Satellite & $\begin{array}{c}\text { Length of ash } \\
\text { plume, } \mathrm{km}\end{array}$ & $\begin{array}{l}\text { Azimuth of plume } \\
\text { movement, deg }\end{array}$ & $\begin{array}{c}\text { Height of ash } \\
\text { plume, } \mathrm{km} \text { a.s.l. }\end{array}$ \\
\hline 1 & 2 & 3 & 4 & 5 & 6 \\
\hline 12 Jul 15 & $16: 45$ & NOAA 19 & 898 & 106 & 4 \\
\hline 12 Jul 15 & 19:15 & NOAA 19 & 1120 & 101 & 3.5 \\
\hline 14 Jul 15 & 18:54 & NOAA 18 & 20 & 217 & 2 \\
\hline 14 Jul 15 & $20: 33$ & NOAA 18 & 59 & 179 & 2 \\
\hline 27 Nov 15 & $15: 00$ & AQUA & 150 & 92 & 5 \\
\hline 27 Nov 15 & $16: 37$ & AQUA & 285 & 96 & 5 \\
\hline 30 Nov 15 & 5:08 & NOAA 18 & 151 & 116 & 6 \\
\hline 19 Jan 16 & $5: 31$ & NOAA 18 & 51 & 107 & 7.5 \\
\hline 19 Jan 16 & 7:08 & NOAA 19 & 78 & 347 & \\
\hline 21 Jan 16 & $6: 46$ & NOAA 18 & 36 & 265 & 4.5 \\
\hline 24 Jan 16 & $0: 17$ & TERRA & 5 & 20 & 7 \\
\hline $24 \operatorname{Jan} 16$ & $1: 21$ & Suomi NPP & 116 & 21 & \\
\hline 24 Jan 16 & $2: 51$ & NOAA 19 & 236 & 22 & \\
\hline 5 Feb 16 & $16: 50$ & Himawari-8 & 5 & 90 & 7 \\
\hline 5 Feb 16 & 20:00 & Himawari-8 & 80 & 92 & \\
\hline 5 Feb 16 & 23:20 & Himawari-8 & 170 & 90 & \\
\hline 9 Feb 16 & 9:10 & MSU & 142 & 102 & \\
\hline 9 Feb 16 & $11: 27$ & Suomi NPP & 295 & 104 & \\
\hline 9 Feb 16 & $15: 35$ & AQUA & 546 & 103 & \\
\hline 12 Feb 16 & $23: 40$ & MSU & 195 & 108 & 10 \\
\hline 13 Feb 16 & $2: 27$ & NOAA 19 & 330 & 108 & \\
\hline 13 Feb 16 & 4:05 & NOAA 19 & 450 & 111 & \\
\hline 13 Feb 16 & $9: 30$ & AQUA & 520 & 98 & \\
\hline 24 Mar 16 & $16: 00$ & AQUA & 96 & 289 & 3.5 \\
\hline 24 Mar 16 & $17: 13$ & NOAA 19 & 134 & 289 & 3.5 \\
\hline 20 Nov 16 & $2: 52$ & NOAA 19 & 73 & 91 & 6.5 \\
\hline 20 Nov 16 & $3: 10$ & AQUA & 150 & 92 & 6 \\
\hline 20 Nov 16 & $4: 29$ & NOAA 19 & 389 & 94 & \\
\hline
\end{tabular}

From October 2014, the pattern was observed that the highest explosive activity occurred after a break in the eruption. As an example, the relative quiet between October 1 and 10 was followed by explosions that hurled ash as high as $8-9 \mathrm{~km}$ a.s.l.; the discharges of ash on November 8 reached a height of $11 \mathrm{~km}$ a.s.l. after the quiet between October 13 and November 7 . The explosions that followed the November 11-21 quiescence again ejected ash to a height of $8.5 \mathrm{~km}$ a.s.l. on November 22 (see Table 1, Fig. 2).

Ash ejections and plumes could occasionally be seen from the town of Petropavlovsk-Kamchatskii and Elizovo; for example, on August 28, September 28, and November 25, 2014; on March 8, 2015; on January 19 and 21, and February 12, 2016 (see Figs. 4b, 4f). The powerful ash explosions that occurred on Novem- ber 25, 2014 caused anxiety to people in the Petropavlovsk-Kamchatskii-Elizovo agglomeration: the wind carried a dark ash cloud southeastward from Zhupanovsky and the cloud projection could be seen coinciding with the Avachinsky summit, when many people believed that they were seeing an eruption of the "home" volcano, but the ash cloud continued traveling seaward, and this anxiety passed (see Fig. 4b).

The volcano was in a state of relative quiet in December 2-14, 16-28, between December 30, 2014 and January 4, 2015, between January 26 and February 5, in February 10-14, and February 23-28, 2015. On other days in November-December 2014 and January-February 2015, ash was ejected to heights of $6 \mathrm{~km}$ a.s.l. and covered the environs of the volcano (see Table 1, Figs. 2, 4c, 5b). It should be said that the ther- 

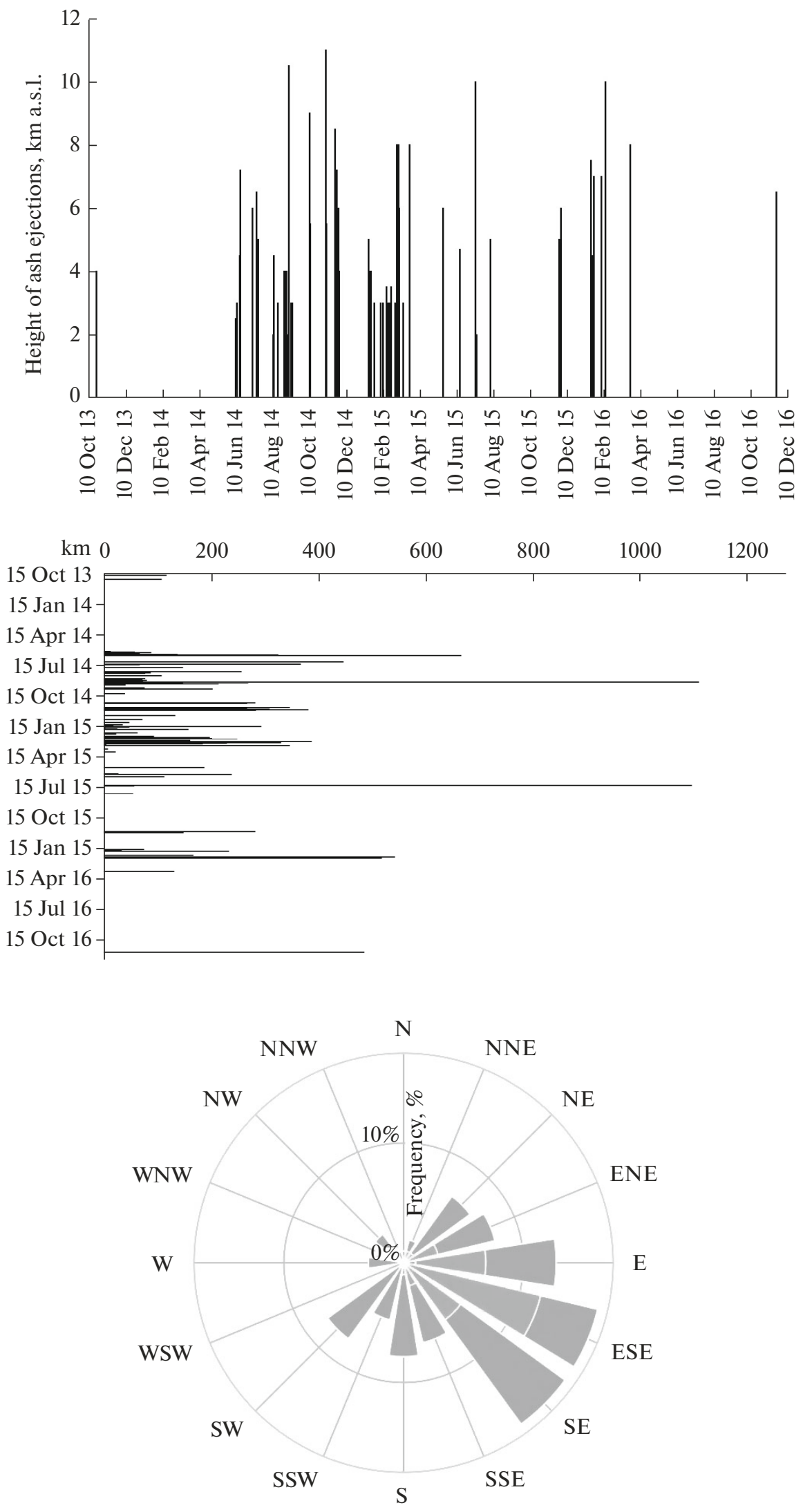

Fig. 2. The height (a), length (b), and directions of propagation (c) of ash plumes discharged by Zhupanovsky Volcano during the eruptions of 2013 and 2014-2016. 


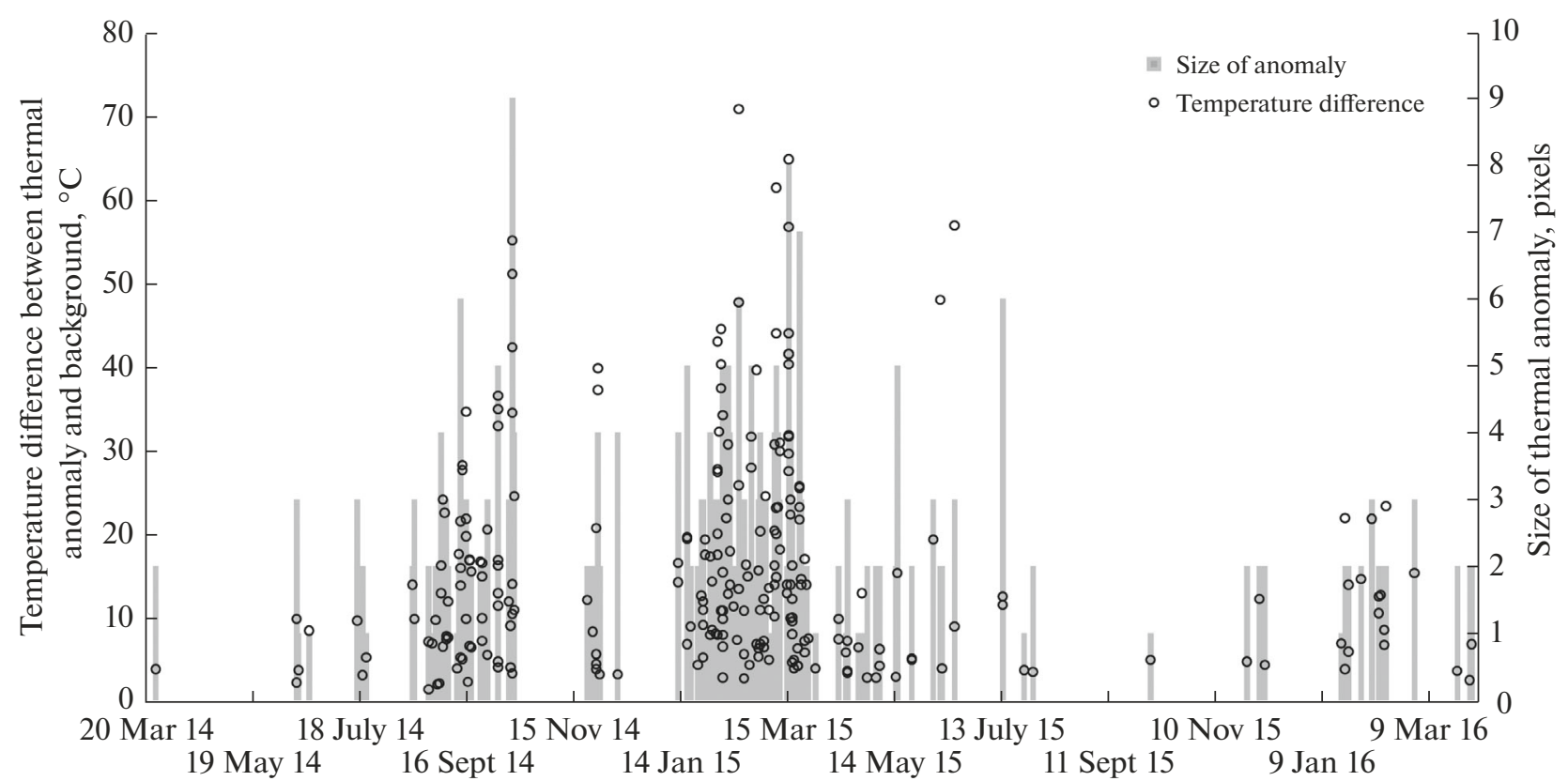

Fig. 3. The temperature and size of the thermal anomaly on Zhupanovsky Volcano during the eruptions of 2013 and $2014-2016$.

mal anomaly in the area of the active vent was not always recorded and sometimes was observed during ash ejections and at other times during intereruptive phases. In other words, the thermal anomaly in the Priemysh area was a reflection of the heat flow coming from the volcano's interior during the discharge of both ash and steam-gas mixture.

The volcano's eruptive activity increased again in March 2015: ash was ejected to heights of $8 \mathrm{~km}$ a.s.l. on March 4, 7, 8, and 25 (VONA KVERT 2015-118 and 2015-138), while on other days in March through June ash plumes were at heights of 4 to $6 \mathrm{~km}$ a.s.l., extending for $400 \mathrm{~km}$ mostly eastward of the volcano (see Table 1, Figs. 2 and 4). As an example, the vertical ash column that stood above the Priemysh Cone on March 8 contained much steam that formed a kind of "cap" on the surface of the spreading cloud (see Fig. 4d). Visual observation showed that steam-gas jets were also mixed with the ash column from the surface of small pyroclastic flows that were descending down hollows on the volcano's slopes and melting the snow, which indicated a high temperature of the eruptive material, among other issues. The upper part of the column gradually became an ash plume.

The number of interruptions in the volcano's eruptive activity increased from March 2015. The intervals of inactivity were as follows: March 5-7, March 1624, from March 26 to April 2, from April 4 to May 19, from May 23 to June 7, June 9-15, and from June 17 to July 11. Ash clouds rather than plumes were observed, which meant that the volcano's eruptive activity was decreasing, with ash being ejected after long intermissions. The ash clouds rose to heights of
4-6 km a.s.1. and could be followed for $100-400 \mathrm{~km}$ from the volcano (see Table 1, Fig. 2).

An unusual event occurred in the Zhupanovsky eruption on July 12, 2015. According to (Senyukov et al., 2015), a sequence of shallow seismic events was recorded in the Zhupanovsky area during $12 \mathrm{~min}$ beginning 06:26 UTC on July 12. Based on satellite data from the VolSatView IS, the explosions sent ash to a height of $10 \mathrm{~km}$ a.s.l., with the ash plume traveling for $1100 \mathrm{~km}$ southeastward and eastward from the volcano during $10 \mathrm{~h}$ (VONA KVERT 2015-179) (see Table 1, Fig. 2). A final event destroyed the southern part of the active Priemysh Cone during or after this episode of vigorous explosive activity of July 12 accompanied by a slide of some of its cone on July 14, although this event involved a smaller volume of material (VONA KVERT 2015-182). According to Gorbach et al. (2015), what was produced by the landslide proper lay in the western sector of the collapse field and the material was cold, with most of the rock blocks consisting of lavas due to summit flows from the Priemysh. The landslide was surrounded by mudflow tongues that extended for at least $10 \mathrm{~km}$. Bushes and trees were crumpled in the immediate vicinity of the front of the deposits, with some of these being overthrown, while signs of thermal or impact effects on the vegetation were observed. A classification of the deposits using tools from the VolSatView IS revealed three characteristic patches in these deposits, with two of them being dated July 12 and one July 14: most of the deposits were formed during or at the end of the July 12 explosive activity of Priemysh; melting of the glaciers and snow patches due to the hot material resulted in mudflows that made a wide blanket over 
(a)

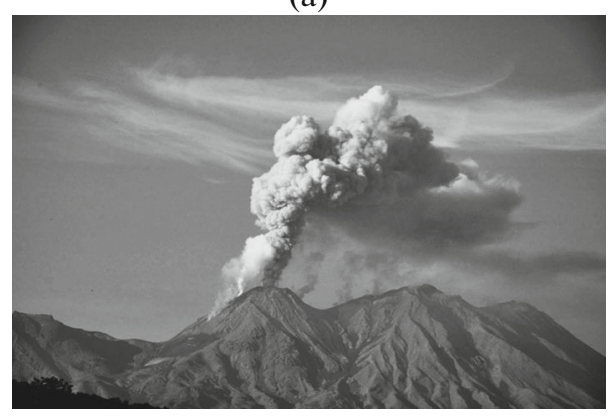

(c)

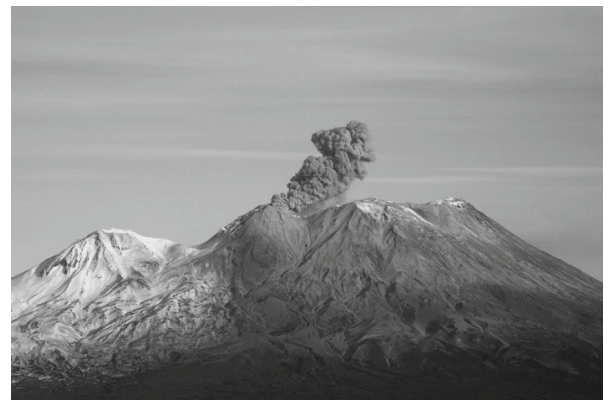

(e)

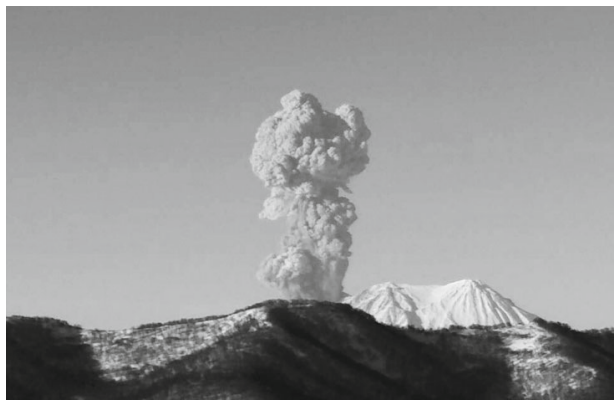

(b)

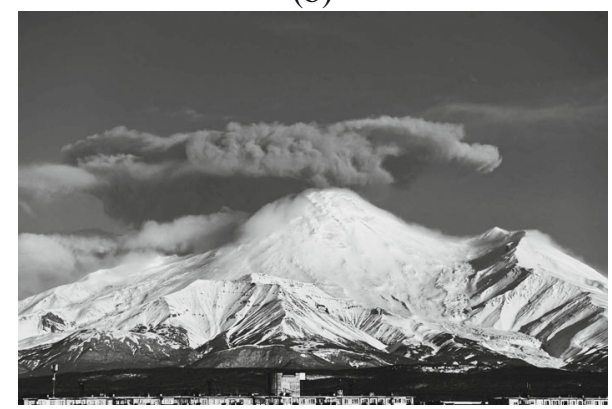

(d)

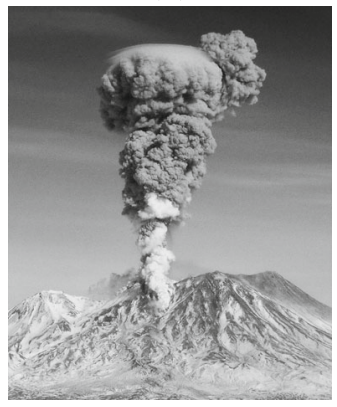

(f)

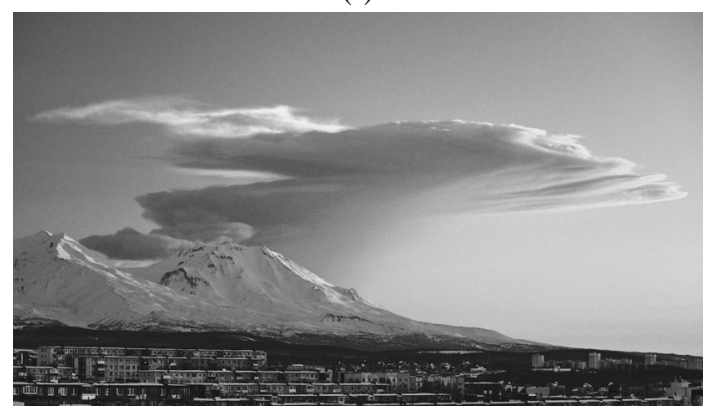

Fig. 4. Examples of explosive activity on Zhupanovsky during the 2014-2016 eruption: July 10, 2014, photographed by E. Nenasheva (a); the projection of the ash cloud of Zhupanovsky onto the summit of Avachinsky Volcano on November 25, 2014, photographed by A. Sokorenko (b); November 28, 2014, photographed by A. Sokorenko (c); March 8, 2015, photographed by A. Gavrilov (d); January 19, 2016, the KB FRC UGS RAS video data (e); February 12, 2016, photographed by A. Sokorenko (f).

the base of the volcano; the July 14 explosions and collapses placed another portion of relatively dry rudaceous material on the western part of the deposit field (Gordeev et al., 2016). The approximate total area of the displaced deposits that were produced during July 12-14 was $20 \mathrm{~km}^{2}$; since the average thickness was $2 \mathrm{~m}$, the volume was $0.04 \mathrm{~km}^{3}$ (Gordeev et al., 2016). The ash plumes ejected July 12-14 went for a few thousands of kilometers east of the volcano and remained in the air above Alaska until July 16 (see Table 1, Fig. 6).

Zhupanovsky was relatively quiet between July 13 and November 27, 2015; the only sign of unrest was some occasional fumarolic activity. Explosions hurled ash to heights of 5-6 km a.s.l. on November 27 and 30; part of the Priemysh Cone was destroyed by these explosions and was deposited on the July 12-14 prod- ucts. A classification of the deposits due to the landslide using tools of the VolSatView IS separated them into fresh deposits, which remained unchanged after the deposition, and those displaced by water resulting from snow and ice melted by hot deposits on the volcano's slope (Gordeev et al., 2016a). The November 30 deposits covered an approximate area of $16 \mathrm{~km}^{2}$ with a thickness of $1.5 \mathrm{~m}$; hence, the volume was $0.02 \mathrm{~km}^{3}$, which is two times lower than that due to the July 1214 collapse (Gordeev et al., 2016a).

The period from December 1 until the end of 2015 was again a period of relative quiet for Zhupanovsky and its eruption seemed to be over, but explosive activity resumed in January 2016 (Girina et al., 2016b). The preceding 50 days of long silence (since November 30 , 2015) gave way to explosions that lifted ash from the Priemysh vent to heights of $8 \mathrm{~km}$ a.s.l.; judging from 

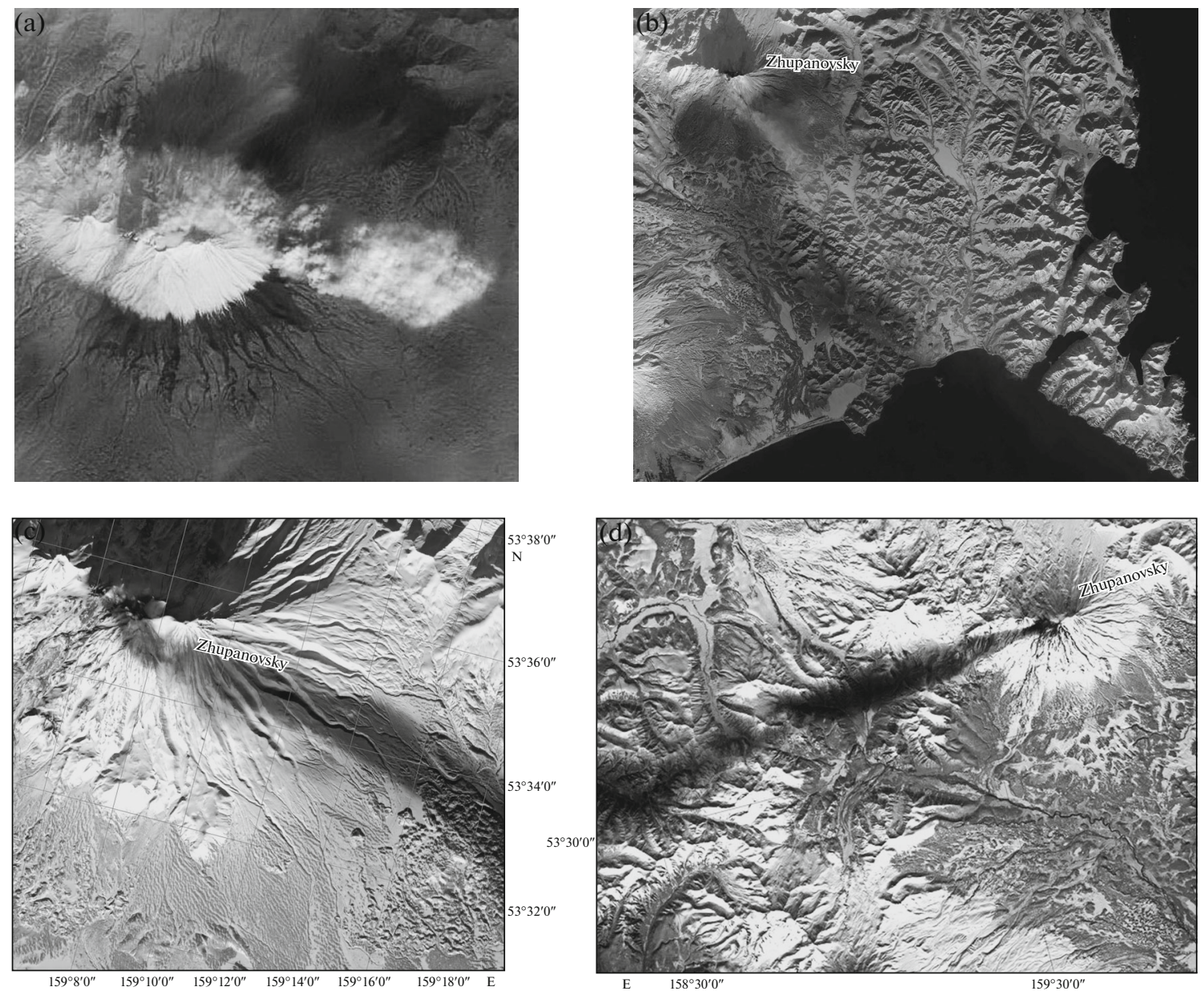

Fig. 5. Examples of ash plumes and deposits discharged by Zhupanovsky Volcano and recorded on satellite imagery: September 28, 2014, Landsat-8 (a); December 1, 2014, Landsat-8 (b); February 6, 2016, Kanopus-V (c); April 1, 2016, Resurs-P no. 2 (d) (a), (b) are NASA, USA data, (c), (d) data from the Planeta Far East Research Center, Khabarovsk.

satellite-borne observations (VolSatView IS), the ash plume traveled along a winding path northwestward of the volcano; a low thermal anomaly was recorded in the Priemysh area after the explosive event (see Table 1, Figs. 2, 3, and 4e) (Girina et al., 2016b). Discrete powerful explosions hurling ash to $7-10 \mathrm{~km}$ a.s.l. were also observed on January 21 and 24, February 5, 7, 9, and 12, March 24, and November 20, with fresh ash deposits being distinctly seen on the snow-clad slopes of the volcano (see Table 1, Figs. 2, 5c, and 5d) (Girina et al., 2016b).

The largest explosive event of 2016 occurred on February 12, hurling ash to heights of $10 \mathrm{~km}$ a.s.l. and completing the destruction of the southern wall in the Priemysh crater (see Fig. 4f) (Girina et al., 2016b). According to satellite data, the front of the ash plume was located at a distance of $195 \mathrm{~km}$ from the volcano at 23:40 UTC on February 12 and at $520 \mathrm{~km}$ at 09:30 UTC on February 13 (see Table 1). The plume traveled eastward from the volcano at first, which was followed by the frontal part of the ash plume being spread out northward and southward in the area of the Shipunskii Peninsula, traveling as a band eastward from the volcano. The subsequent propagation involved further spreading from north to south, with the cloud being driven by a cyclone further northeast of the volcano. The Support Aviation Control Service (SACS) $\mathrm{SO}_{2} \&$ Ash Notification System, http://sacs.aeronomie.be/ reported an aerosol cloud charged with $\mathrm{SO}_{2}$ over against the Shipunskii Peninsula at 22:44 UTC on February 12, while at 08:33 UTC February 13 a cloud that was distended in the north-south direction was found to be south of the Commander Islands of the Aleutian arc. According to the AIRS $\mathrm{SO}_{2}$ data, the maximum concentration of $\mathrm{SO}_{2}$ was $25.2 \mathrm{DU}$ (for the Dobson Unit, see the note to Table 2) in the aerosol cloud $3832 \mathrm{~km}^{2}$ in area at 01:41-01:47 UTC on February 13 and 13.4 DU at 15:11-15:17 UTC, with the cloud having an area of $8099 \mathrm{~km}^{2}$ (Girina et al., 2016b). It should be noted that a low thermal anomaly was recorded in the Priemysh area before the explosive 


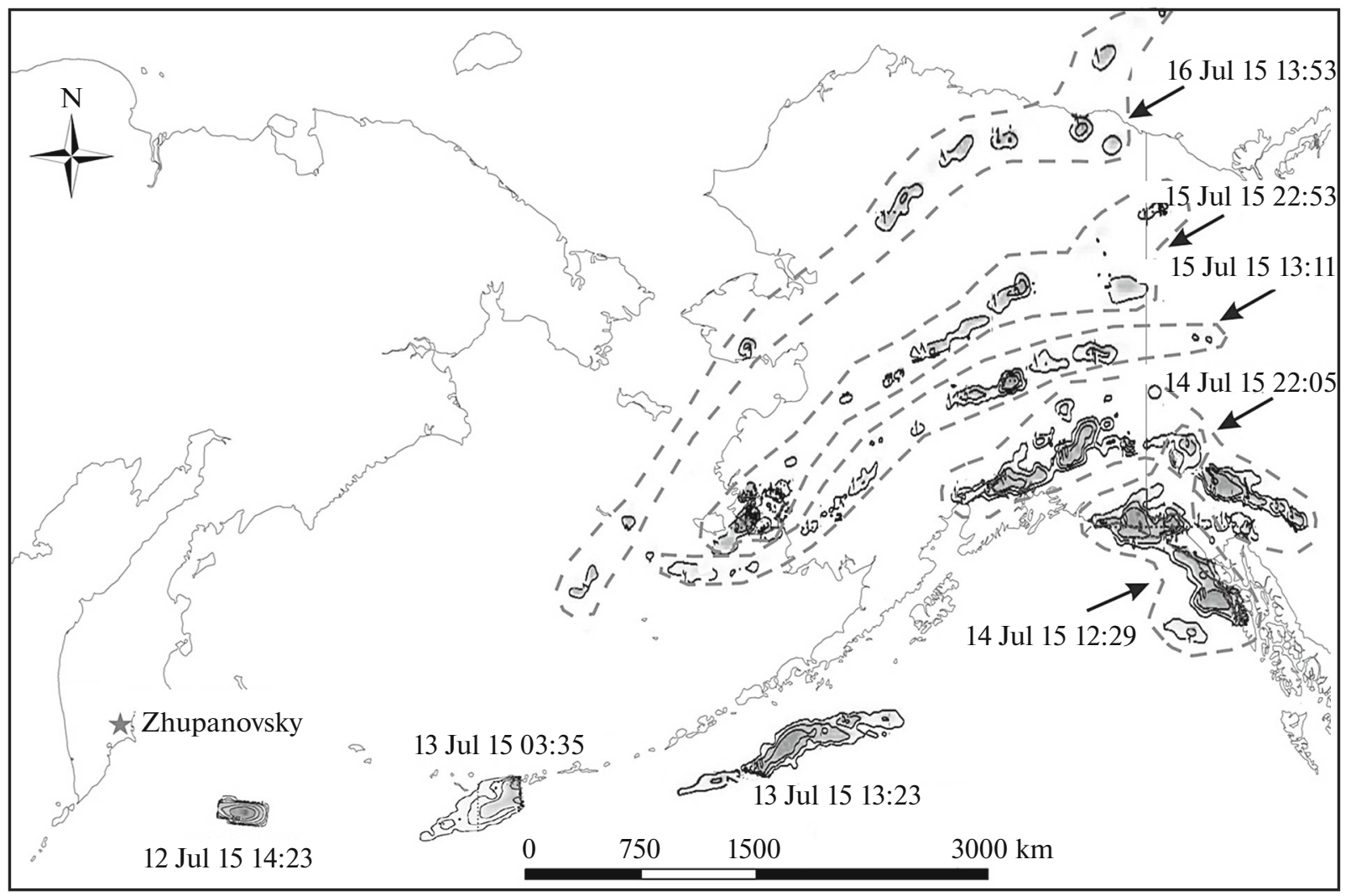

Fig. 6. The propagation of aerosol clouds from Zhupanovsky Volcano following the explosive events of July 12-14, 2015.

Table 2. A characteristic of $\mathrm{SO}_{2}$ emission based on measurements of a satellite-based AIRS instrument (Prata, Bernardo, 2007) during the 2014-2015 eruption of Zhupanovsky Volcano

\begin{tabular}{|c|c|c|c|c|c|}
\hline Date & Time, UTC & $\begin{array}{l}\text { Distance of } \mathrm{SO}_{2} \\
\text { cloud or plume } \\
\text { from volcano, } \mathrm{km}\end{array}$ & $\begin{array}{c}\text { Area of } \mathrm{SO}_{2} \text { cloud } \\
\text { or plume, } \mathrm{km}^{2}\end{array}$ & DU & Mass, in 1000 tons \\
\hline 19 Jun 14 & $16: 23$ & 140 & 5746 & 30.5 & 2.6 \\
\hline 20 Jun 14 & $1: 59$ & 760 & 7823 & 13.8 & 1.3 \\
\hline 7 Sep 14 & $2: 53$ & 200 & 2955 & 39.3 & 2.5 \\
\hline 7 Sep 14 & 14:47 & 1300 & 7388 & 10.9 & 0.8 \\
\hline 8 Nov 14 & $1: 29$ & 78 & 3592 & 23.6 & 1.5 \\
\hline 22 Nov 14 & $15: 11$ & 75 & 937 & 21.4 & 0.5 \\
\hline 25 Nov 14 & $2: 11$ & 71 & 1561 & 41.9 & 1 \\
\hline 8 Mar 15 & $2: 17$ & 95 & 895 & 9.1 & 0.1 \\
\hline $12 \mathrm{Jul} 15$ & $14: 23$ & 620 & 12680 & 95.4 & 15.9 \\
\hline 13 Jul 15 & $1: 35$ & 1700 & 40546 & 49.9 & 9.8 \\
\hline $13 \mathrm{Jul} 15$ & $13: 23$ & 2800 & 43173 & 19.5 & 8.1 \\
\hline $14 \mathrm{Jul} 15$ & $12: 29$ & 3800 & 54885 & 20.3 & 11.7 \\
\hline $14 \mathrm{Jul} 15$ & 22:05 & 3900 & 37075 & 23.2 & 8.8 \\
\hline $15 \mathrm{Jul} 15$ & $13: 11$ & 3200 & 33607 & 19.7 & 2.8 \\
\hline $15 \mathrm{Jul} 15$ & $22: 53$ & 3450 & 30204 & 11.9 & 2.8 \\
\hline 16 Jul 15 & $13: 53$ & 3400 & 11137 & 8.8 & 1.1 \\
\hline
\end{tabular}

DU is the Dobson unit for measuring the concentration of $\mathrm{SO}_{2}$, which is equal to the number of ozone molecules needed to create a pure layer of ozone $0.01 \mathrm{~mm}$ thick at standard conditions for temperature and pressure. 
event, with the temperature of the anomaly slightly increasing $0.5 \mathrm{~h}$ before the explosion (see Fig. 3).

The intermission in the volcano's activity, which lasted 40 days, was followed by a strong explosion that hurled ash to heights of $8 \mathrm{~km}$ a.s.l., with pyroclastic and landslide deposits collapsing toward the base of the Priemysh Cone; ash was deposited over an area of at least $200 \mathrm{~km}^{2}$ (see Fig. 5d) (Gordeev et al., 2016a).

The 2014-2016 Zhupanovsky eruption was terminated by an event that occurred on November 20, 2016: explosions lifted ash from the Priemysh Cone to heights of $7 \mathrm{~km}$ a.s.l. and the ash plume extended for $500 \mathrm{~km}$ eastward of the volcano (see Table 1, Fig. 2) (VONA KVERT 2016-184).

\section{DISCUSSION OF THE OBSERVATIONS}

Plumes containing small amounts of volcanic ash were mostly recorded in 2013 (October 22-24). The plumes extended for $50-120 \mathrm{~km}$ southeast, south, and southwest of the volcano (see Table 1, Fig. 2). Judging from the character and length of the plumes, ash was emitted by fumaroles intermittently, with the greatest amount entering the atmosphere after the conduits had been emptied, nearer the end of the eruption.

The ash that lay on both the volcano's summit and at its base was dusty (Fig. 7), being dominated by resurgent material (fragments of older rocks and altered rocks, as well as fragments of secondary minerals such as quartz and gypsum) (Manevich et al., 2015). Judging by these data, as well as the fact that no high-temperature anomaly was recorded in the area of the volcano during the eruption and the erupted material was not voluminous, one can infer that a phreatic eruption of Zhupanovsky occurred at this time. Fumaroles on the western slope of Priemysh were the centers of powerful blasts of gas that carried small amounts of ash (see Fig. 1) (Girina et al., 2014).

The eruption that lasted between June 6, 2014 and November 20, 2016 was accompanied by ash explosions; ash-charged plumes were recorded on satellite imagery for a total duration of approximately 112 days during 17 months. The explosive activity of 2014-2016 was not uniform: continuous volcanic activity that manifested itself in the greatest number of series of explosions and ash plumes was recorded in June (10 days), July (7 days), August (8 days), September (16 days), and November (11 days) in 2014 and in January (10 days), February (11 days), March (8 days), and July (5 days) in 2015 (see Table 1, Fig. 2). At other times ash plumes were observed on 1-2 days in a month, e.g., on November 27 and 30, 2015; January 19, 21, and 24, February 5, 7, 9, and 12-13, March 24, and November 20, 2016 (Girina et al., 2016, 2016a, 2016b; VONA KVERT 2016-184) (see Table 1, Fig. 2). The highest activity was between June and October, and in November 2014, from January to April 2015, and in January and February 2016, with a well-pro-

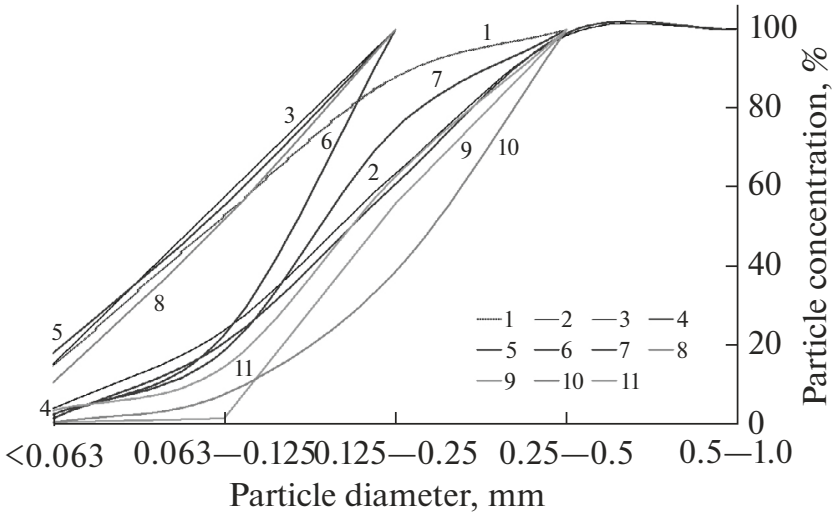

Fig. 7. The cumulative curves of the grain-size composition of the ash erupted from the Priemysh Cone in 2013-2016. Ash sample designation, 2013: (1) southeastern slope of the cone at $1187 \mathrm{~m}$ a.s.l. (the ashfall of October 22-24); 2014: (2) $4 \mathrm{~km}$ east of the cone at $1115 \mathrm{~m}$ a.s.l. (June 7-10); (3) $40 \mathrm{~km}$ east (June 7); 2015: (4) $18 \mathrm{~km}$ westsouthwest (Talovaya Springs) (January 16); (5) $23 \mathrm{~km}$ southwest (Nalychevo Springs) (January 16); (6) $18 \mathrm{~km}$ westsouthwest (Talovaya Springs) (March); (7) $48 \mathrm{~km}$ southeast (Cape Nalychevo) (July 12-13); 2016: (8) 36 km southwest (Pinachevo Pass) (January 21); (9) $18 \mathrm{~km}$ westsouthwest (Talovaya Springs) (January 19-21); (10) $34 \mathrm{~km}$ southeast (Vakhil' R.) (February 13); (11) 46 km east (Lake Kalygir') (November 20).

nounced thermal anomaly being seen almost constantly on satellite imagery in the Priemysh area (see Fig. 3). The grain-size composition of the ash sampled at several distances from the Priemysh Cone (between 4 and $48 \mathrm{~km}$ ) showed prevailing very fine and fine fractions, with the coarser material being discharged by discrete powerful explosive events of 2016 (see Fig. 7).

This high level of activity (powerful discharges of ash to heights of up to $10 \mathrm{~km}$ a.s.l., plumes that were charged with large amounts of ash particles, and a pronounced thermal anomaly in the Priemysh area) could not have been merely phreatic. This was corroborated by studies of ash composition where considerable amounts of juvenile material were found (Gorbach et al., 2016). All the data described above indicate that the eruption was phreatomagmatic in character.

It is known that the velocity of propagation for ash plumes from a volcano depends on the eruption strength (the density of magma pulses, the saturation of plumes with ash particles, etc.) and on the atmospheric parameters (stratification, wind velocity in different layers, etc.) (Asaturov et al., 1986; Encyclopedia of Volcanoes, 2000). Whatever the ash height, spreading and extension of ash plumes perpendicularly or across their downwind displacement were occasionally observed, with the velocity of the ash plumes varying between 35 and $170 \mathrm{~km} / \mathrm{h}$. As an example, video and satellite observations showed the ash plume to rise to heights of $7 \mathrm{~km}$ a.s.l. during the explosive event of November 20, 2016. Data from the Himawari-8 satellite showed that the frontal part of 
the ash plume was traveling at a rate of $140-170 \mathrm{~km} / \mathrm{h}$ between 02:30 and 04:00 UTC on November 20, in keeping with the prevailing wind speeds at those heights on the same day as was obtained from the atmosphere profile.

The high cyclonic activity over Kamchatka frequently complicated the movement of ash plumes. As an example, the Tokyo VAAS reported that explosions hurled ash to heights of $8 \mathrm{~km}$ a.s.l. at 13:20 UTC on March 24, 2016; KVERT satellite-borne observations showed an $8 \times 10-\mathrm{km}$ ash cloud traveling northwest of the volcano for $134 \mathrm{~km}$, while another ash cloud was traveling west-southwest from the volcano at heights of 3.5-4.0 km a.s.1., leaving a trace of ash deposited on the volcano's slopes over an area of at least $200 \mathrm{~km}^{2}$ (see Fig. 5d). The recovery of the March 24 eruptive events was made possible through the tools developed for the VolSatView IS (Gordeev et al., 2016a).

Satellite imagery frequently recorded aerosol clouds that accompanied ash plumes from the beginning of the eruption in 2014 (http://sacs.aeronomie.be). The more powerful an explosive event was, the higher the concentration of $\mathrm{SO}_{2}$ was in aerosol clouds and the longer they existed in the atmosphere (Table 2, see Fig. 6). While the average mass of $\mathrm{SO}_{2}$ during explosions varied between 100 and 2600 tons, the values for the events of July 12 and 14, 2015, which were accompanied by collapses of parts of the Priemysh Cone, whose rocks experienced metasomatic transformations over a long period, were 15900 and 11700 tons, respectively (see Table 2). The increase by an order of magnitude in the mass of $\mathrm{SO}_{2}$ in the July 12 and 14, 2015 aerosols compared with the aerosols due to the explosive events of 2014 and 2015 was caused by the release of $\mathrm{SO}_{2}$ from the destroyed Priemysh rocks as they collapsed onto the volcano's slopes. The smaller volume of the July 14, 2015 collapse deposits resulted in a slightly lower mass of $\mathrm{SO}_{2}$ (see Table 2).

The variation of the configuration and area of aerosol clouds during July $12-16,2015$ is shown in Table 2 and in Fig. 6. After the explosions and the collapse of part of the Priemysh edifice, the aerosol cloud was traveling southeastward from the volcano on July 12 and was observed around the middle of the Aleutian Islands at 01:35 UTC on July 13. The cloud then expanded to become five times longer and was recorded traveling east-northeast along the northern Aleutian Islands at 13:23 UTC on the same day; it extended along the northeastern coast of the Pacific Ocean at 12:29 UTC on July 14. The high cyclone activity in the Alaska area first concentrated the clouds and extended them from northwest to southeast, then separated them into smaller clouds and extended these smaller clouds in a band from southwest to northeast. From 13:11 UTC July 15 until 13:53 UTC July 16 further extension of the band of clouds from southwest to northeast and a northeastward movement were observed (see Fig. 6). Although the area of the aerosol clouds was increasing, the total mass of $\mathrm{SO}_{2}$ in them was gradually diminishing (see Table 2 ).

\section{RESULTS AND CONCLUSIONS}

(1) Due to continuous satellite-based monitoring of Zhupanovsky Volcano using the VolSatView IS, we have been able to provide a detailed description of all explosive events that were occurring on the volcano during the eruptions of 2013 and 2014-2016.

(2) Ash rose to heights of 5-6 km a.s.l. during October 22-24, 2013; the ash plumes extended for as much as $300 \mathrm{~km}$ from the volcano. The 2014-2016 eruption sent ash to heights of $8-10 \mathrm{~km}$ a.s.l.; the plumes were as long as $1100 \mathrm{~km}$ and they mostly moved east and southeast. The highest activity was shown by the volcano from June to October, and in November 2014, from January to April 2015, and in January-February 2016, with a bright thermal anomaly being recorded on satellite images in the Priemysh Cone area.

(3) Aerosol clouds were recorded on satellite images during the large explosive events of 2014-2016. The average mass of $\mathrm{SO}_{2}$ during the explosions varied between 100 and 2600 tons, increasing to 15900 and 11700 tons during the events of July 12 and 14, 2015, respectively, as parts of the Priemysh Cone collapsed, whose rocks had experienced metasomatic transformations over a long period of time.

(4) An integrated analysis of satellite and groundbased data on the Zhupanovsky explosions, as well as of compositions of ash for different periods of the eruptions, helped to refine the information on the phreatic character of the 2013 eruption and the phreatomagmatic eruption in 2014-2016.

\section{ACKNOWLEDGMENTS}

This work was supported by the Russian Science Foundation, project no. 16-17-00042.

\section{REFERENCES}

Asaturov, M.L., Budyko, M.I., Vinnikov, K.Ya., et al., Vulkany, stratosfernyi aerizol' i klimat Zemli (Volcanoes, Stratospheric Aerosol, and Terrestrial Climate), Leningrad: Gidrometeoizdat, 1986.

Bazanova, L.I., Dirksen, O.V., Kulish, R.V., and Kartasheva, E.V., The evolution of neotectonic volcanism at the Zhupanov Mountain Range, Kamchatka, in Vulkanizm i geodinamika (Volcanism and Geodynamics), Proc. IV All-Russia symp. on Volcanology and Paleovolcanology, Petropavlovsk-Kamchatskii: IViS DVO RAN, 2009, vol. 1, pp. 265-268.

Encyclopedia of Volcanoes, Sigurdsson, H., Editor-in-Chief, San Diego, San Francisco, New York, Boston, London, Sydney, Toronto: Academic Press, 2000.

Girina, O.A. and Nenasheva, E.M., The 2013-2015 eruptions of Zhupanovsky Volcano, in Otchizny vernye syny 
(The Fatherland's True Sons), Proc. XXXII Krashenninikov Lectures, Petropavlovsk-Kamchatskii: Krashenninikov Kamchatskaya Kraevaya Nauchnaya Biblioteka, 2015, pp. 172-174. doi 10.13140/RG.2.1. 2125.872010.13140/RG.2.1.2125.8720

Girina, O.A., Manevich, A.G., Mel'nikov, D.V., et al., The activity of Kamchatka volcanoes in 2013, in Vulkanizm $i$ svyazannye s nim protsessy (Volcanism and Associated Processes), Proc. XVII regional conf. devoted to Volcanologist's Day, March 27-28, 2014, PetropavlovskKamchatskii: IViS DVO RAN, 2014, pp. 38-45.

Girina, O.A., Manevich, A.G., Melnikov, D.V., et al., The activity of Kamchatka volcanoes in 2014, in Vulkanizm i svyazannye s nim protsessy (Volcanism and Associated Processes), Proc. XVIII regional conf. devoted to Volcanologist's Day, March 30-April 1, 2015, Petropavlovsk-Kamchatskii: IViS DVO RAN, 2016, pp. 21-25.

Girina, O.A., Manevich, A.G., Melnikov, D.V., et al., The activity of Kamchatka and North Kuril volcanoes in 2015 and their threat to aviation, in Vulkanizm $i$ svyazannye s nim protsessy (Volcanism and Associated Processes), Proc. XIX regional conf. devoted to Volcanologist's Day, March 29-30, 2016, PetropavlovskKamchatskii: IViS DVO RAN, 2016a, pp. 35-45.

Girina, O.A., Manevich, A.G., Mel'nikov, D.V., et al., The explosive activity of Zhupanovsky Volcano in 2016, in Vulkanizm i svyazannye s nim protsessy (Volcanism and Associated Processes), Proc. XIX regional conf. devoted to Volcanologist's Day, March 29-30, 2016, Petropavlovsk-Kamchatskii: IViS DVO RAN, 2016b, pp. 24-34.

Gorbach, N.V., Samoilenko, S.B., Plechova, A.A., and Mel'nikov, D.V., A landslide on Zhupanovsky Volcano, Kamchatka in July 2015: First data and observations, Vestnik KRAUNTs. Ser. Nauki o Zemle, 2015, no. 3, issue 27, pp. 5-11.

Gorbach, N.V., Plechova, A.A., Portnyagin, M.V., and Filosofova, T.M., The composition of volcanic glasses produced by the current eruption of Zhupanovsky Volcano, in Vulkanizm i svyazannye s nim protsessy (Volcanism and Associated Processes), Proc. XIX regional conf. devoted to Volcanologist's Day, March 29-30, 2016, Petropavlovsk-Kamchatskii: IViS DVO RAN, 2016, pp. 46-52.

Gordeev, E.I. and Girina, O.A., Volcanoes and the threat they pose for aviation, Vestnik RAN, 2014, vol. 84, no. 2, pp. 134-142. doi 10.7868/S0869587314020121

Gordeev, E.I., Girina, O.A., Loupian, E.A., et al., The VolSatView information system for monitoring the volcanic activity in Kamchatka and on the Kuril Islands, $J$. Volcanol. Seismol., 2016, vol. 10, no. 6, pp. 382-394. doi 10.7868/S0203030616060043

Gordeev, E.I., Girina, O.A., Loupian, E.A., et al., The VolSatView IS: An integrated data analysis in application to explosive eruptions of Kamchatka volcanoes, Vestnik DVO RAN, 2016a, no. 5, pp. 120-127.

Litvinov, A.F. and Burmakov, Yu.A., The geological structure and Quaternary volcanism of the Zhupanov
Mountain Range, eastern Kamchatka, Vulkanol. Seismol., 1993, no. 2, pp. 16-26.

Manevich, T.M., Gorbach, N.V., and Samoilenko, S.B., Quantitative characteristics and ash composition: The 2013-2015 eruption of Zhupanovsky Volcano, in Vulkanizm i svyazannye $s$ nim protsessy (Volcanism and Associated Processes), Proc. XVIII regional conf. devoted to Volcanologist's Day, March 30-April 1, 2015, Petropavlovsk-Kamchatskii: IViS DVO RAN, 2016, pp. 83-86.

Masurenkov, Yu.P., Florenskii, I.V., and Melekestsev, I.V., Zhupanovsky Volcano, in Deistvuyushchie vulkany Kamchatki (Active Volcanoes of Kamchatka), in 2 vols., Moscow: Nauka, 1991, vol. 2, pp. 216-227.

Prata, A. J., and C. Bernardo, Retrieval of volcanic $\mathrm{SO}_{2}$ column abundance from Atmospheric Infrared Sounder data, J. Geophys. Res., 2007, 112, D20204, doi 10.1029/2006JD007955

Puzankov, M.Yu., Bazanova, L.I., Dirksen, O.V., et al., Hybrid lavas of the Priemysh Cone (Zhupanovsky Volcanic Group, Kamchatka), in Vulkanizm i svyazannye s nim protsessy (Volcanism and Associated Processes), Proc. XVIII regional conf. devoted to Volcanologist's Day, March 30-April 1, 2015, Petropavlovsk-Kamchatskii: IViS DVO RAN, 2016, pp. 139-145.

Samoilenko, S.B., Mel'nikov, D.V., Chirkov, S.A., and Manevich, T.M., The resumed activity of Zhupanovsky Volcano in 2013-2014, Vestnik KRAUNTs, Ser. Nauki o Zemle, 2014, no. 1, issue 23, pp. 21-26.

Senyukov, S.L., Nuzhdina, I.N., Droznina, S.Ya., et al., The 2000-2015 seismicity of the Zhupanovsky Volcano area, in Problemy kompleksnogo geofizicheskogo monitoringa Dal'nego Vostoka Rossii (Problems in the Multidisciplinary Geophysical Monitoring of the Russian Far East), Proc. conf., September 27-October 3, 2015, Petropavlovsk-Kamchatskii, Obninsk: GS RAN, 2015, pp. 106-110.

Sirin, A.N., The state of some volcanoes in Kamchatka at the beginning of 1957, Byull. Vulkanol. Stantsii, 1958, no. 27 , pp. $16-24$.

VONA KVERT 2013-26: http://www.kscnet.ru/ivs/kvert/ van/index.php? $\mathrm{n}=2013-26$

VONA KVERT 2014-07: http://www.kscnet.ru/ivs/kvert/ van/index.php? $\mathrm{n}=2014-07$

VONA KVERT 2015-118: http://www.kscnet.ru/ivs/kvert/ van/index.php? $\mathrm{n}=2015-118$

VONA KVERT 2015-138: http://www.kscnet.ru/ivs/kvert/ van/index.php? $\mathrm{n}=2015-138$

VONA KVERT 2015-179: http://www.kscnet.ru/ivs/kvert/ van/index.php? $\mathrm{n}=2015-179$

VONA KVERT 2015-182: http://www.kscnet.ru/ivs/kvert/ van/index.php? $\mathrm{n}=2015-182$

VONA KVERT 2016-184: http://www.kscnet.ru/ivs/kvert/ van/index.php? $\mathrm{n}=2016-184$

Translated by A. Petrosyan 